\title{
FACTORS AFFECTING THE DECISION TO CHOOSE HEALTHY FOOD AMONG JUNIOR HIGH SCHOOL STUDENTS IN KUPANG, EAST NUSA TENGGARA
}

\author{
Inang Fitriani Abdullah'), Intje Picauly2), Sarci M. Toy') \\ 1)Indonesian Child Protection Commission, Kupang \\ 2)Masters Program in Public Health, Nusa Cendana University, Kupang
}

\begin{abstract}
Background: Poor eating habits are an important public health issue that has large health and economic implications. There are other outcomes of food choice and nutrition that also have an independent effect on health including some types of cancer, cardiovascular disease, and diabetes. For these reasons, food selection is an important consumer behavior with many long-term consequences to the individual in the form of health and longevity and to society in the form of health costs. This study aimed to determine factors affecting the decision to choose healthy food among junior high school students in Kupang, East Nusa Tenggara.
\end{abstract}

Subjects and Method: This was a cross sectional study conducted at Islamic junior high state school Plus Nurul Iman Kupang, East Nusa Tenggara on November to December 2016. A total sample of 127 students was selected for this study by simple random sampling. The dependent variable was the decision to choose healthy snacks. The independent variables were knowledge, attitude, practice, maternal education, student allowance, exposure to advertisement, and peer influence. The data were collected by questionnaire and analyzed by a multiple logistic regression.

Results : Good knowledge $(\mathrm{OR}=2.09 ; 95 \% \mathrm{CI}=1.32$ to $3.13 ; \mathrm{p}=0.003)$, positive attitude $(\mathrm{OR}=1.29 ; 95 \% \mathrm{CI}=1.32$ to $2.13 ; \mathrm{p}=0.031)$, good practice $(\mathrm{OR}=1.8 ; 95 \% \mathrm{CI}=1.32$ to 5.13 ; $\mathrm{p}=0.016)$, exposure to advertisement $(\mathrm{OR}=1.79 ; 95 \% \mathrm{CI}=1.32$ to $3.13 ; \mathrm{p}=0.033)$, and peer influence $(\mathrm{OR}=2.79 ; 95 \% \mathrm{CI}=1.32$ to $3.43 ; \mathrm{p}=0.023)$ were associated with the decision to choose healthy snacks.

Conclusion: Good knowledge, positive attitude, habit, exposure to advertisement, and peer influence, are associated with the decision to choose healthy snacks.

Keywords: knowledge, attitude, practice, exposure to advertisement, peer influence, healthy snacks.

\section{Correspondence:}

Inang Fitriani Abdullah. Masters Program in Public Health, Nusa Cendana University, East Nusa Tenggara. Email: picaulyince@yahoo.co.id. Mobile: 082237145517.

The $5^{\text {th }}$ International Conference on Public Health Best Western Premier Hotel, Solo, Indonesia, February 13-14, 2019 | 179 https://doi.org/10.26911/theicph.2019.02.24 